\title{
Front Matter: Volume 8178
}

, "Front Matter: Volume 8178," Proc. SPIE 8178, Optics in Atmospheric Propagation and Adaptive Systems XIV, 817801 (21 October 2011); doi: 10.1117/12.912545

SPIE. Event: SPIE Remote Sensing, 2011, Prague, Czech Republic 


\section{PROCEEDINGS OF SPIE}

\section{Optics in Atmospheric Propagation and Adaptive Systems XIV}

Karin Stein

John D. Gonglewski

Editors

20 September 2011

Prague, Czech Republic

Sponsored by

SPIE

Cooperating Organisations

EOS- European Optical Society

Remote Sensing and Photogrammetry Society

(United Kingdom)

Published by

SPIE 
The papers included in this volume were part of the technical conference cited on the cover and title page. Papers were selected and subject to review by the editors and conference program committee. Some conference presentations may not be available for publication. The papers published in these proceedings reflect the work and thoughts of the authors and are published herein as submitted. The publisher is not responsible for the validity of the information or for any outcomes resulting from reliance thereon.

Please use the following format to cite material from this book:

Author(s), "Title of Paper," in Optics in Atmospheric Propagation and Adaptive Systems XIV, edited by Karin Stein, John D. Gonglewski, Proceedings of SPIE Vol. 8178 (SPIE, Bellingham, WA, 2011) Article CID Number.

ISSN 0277-786X

ISBN 9780819488053

Published by

SPIE

P.O. Box 10, Bellingham, Washington 98227-0010 USA

Telephone +1 3606763290 (Pacific Time) · Fax +1 3606471445

SPIE.org

Copyright (C) 2011, Society of Photo-Optical Instrumentation Engineers

Copying of material in this book for internal or personal use, or for the internal or personal use of specific clients, beyond the fair use provisions granted by the U.S. Copyright Law is authorized by SPIE subject to payment of copying fees. The Transactional Reporting Service base fee for this volume is $\$ 18.00$ per article (or portion thereof), which should be paid directly to the Copyright Clearance Center (CCC), 222 Rosewood Drive, Danvers, MA 01923. Payment may also be made electronically through CCC Online at copyright.com. Other copying for republication, resale, advertising or promotion, or any form of systematic or multiple reproduction of any material in this book is prohibited except with permission in writing from the publisher. The CCC fee code is 0277-786X/11/ \$18.00.

Printed in the United States of America.

Publication of record for individual papers is online in the SPIE Digital Library.

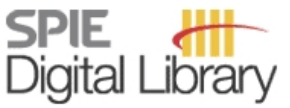

SPIEDigitalLibrary.org

Paper Numbering: Proceedings of SPIE follow an e-First publication model, with papers published first online and then in print and on CD-ROM. Papers are published as they are submitted and meet publication criteria. A unique, consistent, permanent citation identifier (CID) number is assigned to each article at the time of the first publication. Utilization of CIDs allows articles to be fully citable as soon as they are published online, and connects the same identifier to all online, print, and electronic versions of the publication. SPIE uses a six-digit CID article numbering system in which:

- The first four digits correspond to the SPIE volume number.

- The last two digits indicate publication order within the volume using a Base 36 numbering system employing both numerals and letters. These two-number sets start with 00, 01, 02, 03, 04, $05,06,07,08,09,0 A, 0 B \ldots 0 Z$, followed by 10-1Z, 20-2Z, etc.

The CID number appears on each page of the manuscript. The complete citation is used on the first page, and an abbreviated version on subsequent pages. Numbers in the index correspond to the last two digits of the six-digit CID number. 


\section{Contents}

vii Conference Committee

\section{SESSION 1 IR IMAGING}

817802 Seasonal trends and nightly fluctuations of SWIR air-glow irradiance [8178-01]

D. C. Dayton, J. Allen, R. Nolasco, Applied Technology Associates (United States);

J. D. Gonglewski, M. Myers, G. Fertig, Air Force Research Lab. (United States)

817803 Spatial and temporal variability of SWIR airglow measurements [8178-02]

J. Allen, D. Dayton, Applied Technology Associates (United States); G. Fertig, J. Gonglewski, M. Myers, Air Force Research Lab. (United States); R. Nolasco, Applied Technology Associates (United States)

817804 Investigations of SNR for a short-wave infrared intensity interferometer [8178-03] J. Murray-Krezan, Air Force Research Lab. (United States); D. Dayton, J. Allen, Applied Technology Associates (United States); J. Gonglewski, M. Myers, Air Force Research Lab. (United States); R. Nolasco, Applied Technology Associates (United States); G. Fertig, Air Force Research Lab. (United States)

817805 Validation of the background simulation model MATISSE: comparing results with MODIS satellite images [8178-04]

C. Schweitzer, K. Stein, N. Wendelstein, Fraunhofer-Institut für Optronik, Systemtechnik und Bildauswertung (Germany); L. Labarre, K. Caillault, S. Fauqueux, C. Malherbe, A. Roblin, B. Rosier, P. Simoneau, ONERA (France)

817806 Multiresolution infrared optical properties for Gaussian sea surfaces computations: comparison against the MIRAMER campaign measurements in solar glint configurations [8178-05]

S. Fauqueux, S. Langlois, C. Malherbe, K. Caillault, L. Labarre, The French Aerospace Lab., ONERA (France)

\section{SESSION 2 CHARACTERIZATION OF TURBULENCE}

817808 Marine boundary layer investigations in the False Bay, supported by optical refraction and scintillation measurements [8178-07]

A. N. de Jong, A. M. J. van Eijk, K. W. Benoist, TNO Defence, Security and Safety (Netherlands); W. H. Gunter, G. Vrahimis, F. J. October, Institute for Maritime Technology (South Africa)

817809 Stability and height dependant variations of the structure function parameters in the lower atmospheric boundary layer investigated from measurements of the long-term experiment VERTURM (vertical turbulence measurements) [8178-08]

D. Sprung, P. Grossmann, E. Sucher, K. Weiss-Wrana, K. Stein, Fraunhofer-Institut für Optronik, Systemtechnik und Bildauswertung (Germany) 
8178 OA Ground-based solar astrometric measurements during the PICARD mission [8178-09] A. Irbah, M. Meftah, LATMOS-IPSL, CNRS, Univ. Versailles St.-Quentin (France); T. Corbard, Observatoire de la Côte d'Azur, CNRS, Univ. de Nice Sophia Antipolis (France); R. Ikhlef, Ctr. de Recherche en Astronomie, Astrophysique et Géophysique, Observatoire d'Alger (Algeria); F. Morand, P. Assus, Observatoire de la Côte d'Azur, CNRS, Univ. de Nice Sophia Antipolis (France); M. Fodil, Ctr. de Recherche en Astronomie, Astrophysique et Géophysique, Observatoire d'Alger (Algeria); M. Lin, E. Ducourt, P. Lesueur, G. Poiet, LATMOS-IPSL, CNRS, Univ. Versailles St.-Quentin (France); C. Renaud, Observatoire de la Côte d'Azur, CNRS, Univ. de Nice Sophia Antipolis (France); M. Rouze, Ctr. National d'Études Spatiales (France)

$8178 \mathrm{OB}$ Coherence of Bessel beams propagating in turbulent media [8178-10] I. P. Lukin, V.E. Zuev Institute of Atmospheric Optics (Russian Federation)

$81780 \mathrm{C}$ Statistical properties of density fluctuations in the atmosphere [8178-11] F. V. Shugaev, L. S. Shtemenko, O. I. Dokukina, O. A. Nikolaeva, T. A. Petrova, O. A. Solenaya, M. V. Lomonosov Moscow State Univ. (Russian Federation)

\section{SESSION 3 PROPAGATION THROUGH TURBULENT MEDIA}

8178 OD Increase of adaptive correction efficiency of turbulent distortions on basis of measurements by the Shack-Hartmann wavefront sensor [8178-12] L. V. Antoshkin, V. V. Lavrinov, L. N. Lavrinova, V. P. Lukin, V.E. Zuev Institute of Atmospheric Optics (Russian Federation)

8178 OF Imaging through turbulence with temporally and spatially multiplexed systems [8178-23] G. Vdovin, O. Soloviev, M. Loktev, S. Savenko, Flexible Optical B.V. (Netherlands)

\section{SESSION 4 WAVEFRONT CORRECTION}

8178 0G Development of adaptive optics devices for solar telescope [8178-16]

L. V. Antoshkin, O. N. Emaleev, N. N. Botugina, P. A. Konyaev, E. A. Kopylov, V.E. Zuev Institute of Atmospheric Optics (Russian Federation); V. P. Lukin, Tomsk State Univ. (Russian Federation)

$8178 \mathrm{OH}$ Compensating aberrations of a 6 -inch concave membrane mirror [8178-17] I. Buske, Deutsches Zentrum für Luft- und Raumfahrt e.V. (Germany); P. Becker, Fachhochschule Koblenz (Germany)

8178 0l New phasor reconstruction for speckle imaging [8178-18]

G. C. Dente, GCD Associates (United States); M. L. Tilton, Boeing-SVS, Inc. (United States)

$8178 \mathrm{0J}$ Compensating atmospheric distortions of point sources and extended objects through an adaptive iterative procedure [8178-19]

C. Scheifling, G. Marchi, Fraunhofer-Institut für Optronik, Systemtechnik und Bildauswertung (Germany) 
8178 OK Software-based turbulence mitigation of short exposure image data with motion detection and background segmentation [8178-20]

C. S. Huebner, Fraunhofer-Institut für Optronik, Systemtechnik und Bildauswertung (Germany)

\section{POSTER SESSION}

$81780 \mathrm{M}$ Coherent beam combining of collimated fiber array based on target-in-the-loop technique [8178-21]

X. Li, Institute of Optics and Electronics (China) and Key Lab. on Adaptive Optics (China);

C. Geng, Institute of Optics and Electronics (China), Key Lab. on Adaptive Optics (China), and Graduate Univ. of the Chinese Academy of Sciences (China); X. Zhang,

C. Rao, Institute of Optics and Electronics (China) and Key Lab. on Adaptive Optics (China)

$81780 \mathrm{~N}$ A novel wavefront sensing technique for high speed atmospheric measurement based on digital micromirror device [8178-22]

P. Yang, Key Lab. on Adaptive Optics (China) and Institute of Optics and Electronics (China); S. Wang, Key Lab. on Adaptive Optics (China), Institute of Optics and Electronics (China), and Graduate Univ. of the Chinese Academy of Sciences (China);

M. Ao, Univ. of Electronic Science and Technology of China (China); B. Xu, Key Lab on Adaptive Optics (China) and Institute of Optics and Electronics (China)

Author Index 
Downloaded From: https://www.spiedigitallibrary.org/conference-proceedings-of-spie on 26 Apr 2023

Terms of Use: https://www.spiedigitallibrary.org/terms-of-use 


\title{
Conference Committee
}

\author{
Symposium Chair
}

Karin Stein, Fraunhofer-Institut für Optronik, Systemtechnik und Bildauswertung (Germany)

Symposium Co-Chair

Charles R. Bostater, Florida Institute of Technology (United States)

Conference Chairs

Karin Stein, Fraunhofer-Institut für Optronik, Systemtechnik und Bildauswertung (Germany)

John D. Gonglewski, European Office of Aerospace Research and Development (United Kingdom)

Program Committee

Sylvain Cheinet, Institut Franco-Allemand de Recherches de Saint-Louis (France)

David C. Dayton, Applied Technology Associates (United States)

Denis Dion, Jr., Defence Research and Development Canada (Canada)

Stephen M. Hammel, Space and Naval Warfare Systems Command (United States)

Vladimir P. Lukin, V.E. Zuev Institute of Atmospheric Optics (Russian Federation)

Charles L. Matson, Air Force Research Laboratory (United States)

Sergio R. Restaino, U.S. Naval Research Laboratory (United States)

Jennifer C. Ricklin, Lockheed Martin Corporation (United States)

Jim Riker, Air Force Research Laboratory (United States)

Marc J. F. Séchaud, ONERA (France)

Alexander M. J. van Eijk, TNO Defence, Security and Safety (Netherlands)

Arthur D. van Rheenen, Norwegian Defence Research Establishment (Norway)

Mikhail A. Vorontsov, University of Dayton (United States)

Session Chairs

$1 \quad$ IR Imaging

Karin Stein, Fraunhofer-Institut für Optronik, Systemtechnik und Bildauswertung (Germany) 
2 Characterization of Turbulence

Vladimir P. Lukin, V.E. Zuev Institute of Atmospheric Optics (Russian Federation)

3 Propagation through Turbulent Media

David C. Dayton, Applied Technology Associates (United States)

$4 \quad$ Wavefront Correction

John D. Gonglewski, European Office of Aerospace Research and Development (United Kingdom) 